\title{
ANÁLISE DE DOIS TIPOS DE FICÇÃo ${ }^{463}$
}

\author{
OSWALD DE ANDRADE
}

O romance alheio às conquistas científicas de seu tempo, o romance que é feito pelo autor com a simples mudança dos caracteres mais visíveis dos seus vizinhos de rua e a sequiência anedótica do que ele conhece de suas vidas - não passa de material colhido. $\mathrm{O}$ que distingue um grande romancista como Aldous Huxley não é somente a acuidade da sua visão, da sua cultura de vida, da sua pressão literária. É sobretudo isto: que romances como Contraponto ou como Eyeless in Gaza, só podiam ter sido escritos a par dos imensos territórios conquistados pela ciência nos dias de hoje. A biologia, a física, como a psicologia de Huxley são o testemunho do que vale o estado atual dos conhecimentos humanos empregados na criação literária.

Tentando realizar um corte na sociedade paulista num romance cíclico, procuro estudar a criação de meus personagens à luz das conquistas da psicologia contemporânea. É a razão por que me encontro, leigo e pouco armado, entre vós homens de ciência. Não posso conceber o afastamento do escritor do convívio dos cientistas. Venho pois oferecer hoje, à vossa crítica, o meu esforço.

Escolhi para apresentar-vos dois tipos. Esses dois personagens de Marco zero, que é o título de meu livro, são produtos não somente temperamentais, mas também produtos sociais, levados um à esquisofrenia, outro a uma acentuação da paranóia, que nele larvava, pelos choques violentos de um mundo em crise. A nossa sociedade tem qualquer coisa da fábula de Erostrato. Reduzida às forças narcisistas primárias, ela ateia facilmente fogo às conquistas éticas. Donde resulta o sem-núnrero de incendiados mentais, que nos hospícios ou fora deles conduzem a desordem de suas tochas ativas.

Xavier e a Veva são os nomes escolhidos para esses dois tipos do meu romance, que através do entrecho desenvolvem a sua curva neurótica.

Xavier é a figura do pingente. Nunca encontrou assento cômodo num banco da existência. Vive no estribo social de uma casa rica, a residência da viúva Junquilho, no Jardim América. É o tipo do tio pobre. A origem de Xavier é obscura. Em torno de seu nascimento, jogou-se um alto drama da fazenda feudal, que ele ignora. A princípio foi esmeradamente educado. Mas a morte de um irmão não bastardo, que era o esteio do clã aristocrático e para ele um protetor carinhoso, reduziu-o ao homem debonário e sem finalidades, que paga os impostos, espera horas nas caudas de guichê, põe cartas no correio e ergue a cortina de aço ondulado de um depósito de firma, onde não chega a ter emprego. Xavier é um frustrado. Não o deixam incorporar-se à família rica de que se origina e também não pode construir a sua vida autônoma de pobre. É um tímido. Os seus recalques fazem dele um interpretativo com impulsos masoquistas.

Vamos encontrar Xavier freqüentador do Cinema Pedro II. Aí, nesse buraco da cidade, dissimulado entre árvores, se desenvolvem os "oestes", na tela sensacional dos espetáculos baratos. Uma população de malogrados, de adultos físicos paralisados em infância psíquica, realiza-se através dos filmes, nas façanhas incríveis do mocinho, nas lutas contra o vilão, nos miraculosos salvamentos da heroína. Um desejo latente de justiça social, de justiça humana, vai catartizar-se, para aquele público de meios homens e de meias mulheres, nas cenas cavalheirescas dos romances em série. Como ali o mal é sempre castigado, ao contrário do que sucede na vida, na fita de aventuras a que se deu o nome de "oeste" vão desembocar todos os desejos de vindita dos tímidos e dos oprimidos, que não têm coragem de ação própria. Para

\footnotetext{
${ }^{463}$ Palestra proferida no I Congresso Paulista de Psicologia e Psiquiatria, julho de 1938 (separata).
} 
Xavier, o Pedro II é uma condição de equilíbrio. Nunca uma ruga de dúvida atingiu a sua alma em estado quietista. O que longamente sofreu lá fora, o que diariamente lhe oferecem como ração de deserdado, tem ali o seu desafogo tranqüilizante. $\mathrm{Na}$ intimidade das flores e cristais, por ocasião das festas de aniversário da casa rica, onde é admitido, Xavier narra atrapalhado as fitas a que assistiu, com gáudio da sociedade grã-fina que o goza.

Certa noite, não havendo lugar na platéia do cinema, o habitué é colocado numa frisa ao lado de gente desconhecida e assiste com espanto a uma rixa de casal. O marido ri sarcasticamente do filme heróico e a mulher sentimental reage. $\mathrm{O}$ homem insulta o filme, o público, o cinema modesto, chamando aquilo tudo de bobagem e produz-se na frisa um começo de escândalo. A esposa em lágrimas deixa o teatro acompanhando aquele brutamontes que não compreende o benefício emocional dos "oestes".

Mas a dúvida penetrou no espírito de Xavier. Assustado, ele não consegue mais vitalizar os episódios heróicos que vê. Daí por diante está envenenado o seu desafogo semanal. Quando volta ao Pedro II, uma interrogação o aflige: “Será que essa fita presta?". Na tela desenvolvem-se os mesmos temas bravios e justiçadores. Mas Xavier desconfia: "Será que presta? Não é bobagem?".

A dúvida abriu brecha no quietismo inofensivo de Xavier. Na pensão onde mora, as moças da casa - pequenas funcionárias, criadas, filhas da dona - notam o seu ar deprimido e preocupado. Uma delas tem a idéia de pedir a uma estação da cidade que irradie uma valsa em sua homenagem. Xavier enrubesce exaltado, escutando diante do aparelho o seu nome. "Ao nosso prezado ouvinte Durvalino da Silva Xavier". E eis que uma série de agitações inesperadas aumenta a cunha posta no mundo fechado de sua psique. Os jornais aparecem cheios de fotografias do ministro da Guerra, em visita a São Paulo, em companhia de um chefe de Estado sul-americano. É o general Napoleão Varela, que fora seu companheiro de dormitório no colégio da infância. Um complexo acorda seu íntimo, onde jazia esquecida uma cena noturna do internato. Varela, magro, nervoso e brutal, reaparece agora para ele em todo o esplendor realizado de sua carreira macha. Uma manhã, o Triângulo se atropela da multidão que aclama os visitantes ilustres da cidade. Xavier reconhece o seu antigo companheiro de quarto. Num carro aberto, ao lado do presidente, precedido por sereias violentas, entre cavalos e couraceiros, Napoleão Varela passa nas condecorações cintilantes, entre alamares e dragonas felpudas. Aquele luxo de símbolos "freudianos" acorda um impulso masoquista na alma tímida do pingente. Numa ânsia de verificação, quer saber se aquele homem em apogeu o reconhece e é capaz de considerá-lo. Muitos dias, Xavier espreita obcecado os passos do senhor ministro. Tenta visitá-lo. Manda um abraço pelo porteiro insolente do Hotel Esplanada, que o barra. E, ao sair de uma noite, o seu impulso, animado pela manifestação coletiva, não mais se contém. Atravessa a multidão que aclama o carro oficial. Vai chegar ao estribo, gritar, dar-se a conhecer, receber talvez uma estocada de Napoleão Varela.

Mas a chegada do general, acompanhando o presidente sul-americano, excitara outros anseios anônimos da cidade. Bem no coração do Triângulo paulista, na pequena travessa que liga a Rua Álvares Penteado à Rua 15 de Novembro, travessa que toma nome de "Beco do Escarro", nos botecos de pinga e batida, nos cafés encardidos, açoita-se um bando nervoso de vadios e boêmios fracassados. Heróis do biscate, mitômanos do lucro, artistas incompreendidos, planadores humanos deixados no espaço alcoolizado pelos aperitivos filados nas manhãs ativas - esses homens procuram no tumulto da cidade coberta de festões e de galas a possibilidade de obter o que eles chamam uma "sorridente nota", destinada a apaziguar sua sede contínua. Um verdadeiro "complô", com caráter conspirativo dos grandes atentados, prepara-se nos caminhos do Beco, onde tumultua a São Paulo indiferente dos negócios. Um dos cachaceiros é sorteado para vender ao homem de Estado um mapa da Revolução Paulista, por dez mil réis. Postam-se todos à passagem do cortejo, incitando o golpe. O sorteado consegue entregar o rolo de papel à vítima que, sorrindo entre luvas brancas, exclama "Muchas gradas, caballero!", enquanto Xavier, do outro lado, também 
corre sobre o carro, para se fazer ver por Varela. O tumulto cresce na grita dos boêmios logrados, que reclamam o dinheiro aos berros. A polícia investe contra os desordeiros e os prende. Os jornais noticiam em altas "manchetes" que o presidente e o ministro foram vítimas de um atentado comunista. Xavier e os planadores do Beco são jogados num cárcere soturno.

Um rapaz fino, de voz feminina, cabelo engomado e paletó xadrez, ao vê-lo entrar na prisão, pergunta-lhe aflito se os cadetes do Alcazar de Toledo ainda resistem. Há um ladrão gordo perto dele. Atrás, um homem pacífico que falsificou o seu título eleitoral. Há militantes vermelhos, excitados como feras. Em frente, no cubículo das mulheres, passam escandalosas prostitutas, que gritam e se exibem. Os subterrâneos da sociedade capitalista abrem-se vivamente para Durvalino da Silva Xavier. O seu impulso, ante a ferocidade inesperada do castigo, caiu completamente. Nas noites insones sucedem-se cenas. O rapaz de voz fina mostra por que tanto se interessava pelos barbudos cadetes do Alcazar. No espírito de Xavier isso aumenta a vitória espetacular de Napoleão Varela. Os boêmios do Beco fazem roda com o pingente, perguntando se ele queria "morder" o general. Os dias iguais e sem esperança do cárcere se sucedem, mas no Esplanada o presidente tem um caso de amor e, magnânimo, pede à polícia que relaxe a prisão dos turbulentos.

O pingente, avacalhado e confuso, reaparece no clima milionário do Jardim América. À noite, restituído ao seu quarto dos fundos da pensão, voltam-lhe no sono os subterrâneos que conheceu. As prostitutas, o rapaz dos cadetes... Xavier desemboca estouvadamente no sexual - numa pitoresca composição da adolescência perdida.

Até aí, ele fora tolerado na casa rica da viúva Junquilho, que nunca lhe deixara perceber ser sua cunhada. Vivia na copa, de risos com o chofer Pavuna, com a criadagem, com as crianças. Deixavam-no comparecer à mesa faustosa dos aniversários. Era o tio pobre a quem davam, a troco de serviços, uma mesada para viver.

Xavier torna-se agora um cliente refinado e emocional das casas baratas de tolerância, onde acaba sendo indesejável. A esse tempo, uma negra velha, que fora escrava da família, faz-lhe uma revelação: ele é filho natural da matriarca Veva, que está no Juqueri, depois de arruinada pela viúva Junquilho e seus advogados. E o Pavuna lhe diz que o presidente mandou libertá-lo em homenagem a uma senhora que freqüenta a casa e que ele supunha ser a virtude em pessoa. Xavier descobre que, fora das zonas públicas, o amor ilegal também floresce. Uma série de agressões sexuais, produzidas em criadinhas, depois em parentas pobres, alarmaram a Junquilho. Admitido ainda a um jantar de aniversário, o seu arranco sexual culmina ante a "chance" de se ver sentado ao lado da senhora que tivera a aventura presidencial. Não tarda a incomodá-la por sob a mesa. Repelido, fala no "caso do Esplanada". O escândalo é levado a Junquilho, que resolve interpelá-lo de uma vez para sempre, em conselho de família. Uma noite ele é chamado. E explode numa linguagem que faz o efeito de um ataque aéreo na casa tranqüila, modorrando entre árvores. Deixam-no só, entregue a um pavoroso exame de consciência, no salão Luiz XV. As portas são ferozmente vigiadas pela criadagem, de vassoura em punho. Vão mandar vir os médicos e pô-lo no Juqueri. Xavier enlouqueceu.

Naquele chão frio, onde nada o prende aos confortos da infância, onde quadros e móveis são estranhos à sua vida, resta ali para ele um único liame - o velho álbum de capa de madrepérola, onde figuram ainda fotografias suas de camisinha e cabelos cacheados. Ele fita aí o retrato do irmão falecido, que fizera da sua infância um paraíso de criança adulada, perdida depois no mundo hostil da incompreensão e do desânimo. Chegam os médicos, abrem cautelosamente a porta. Ele os conhece. Um traz uma maleta, para dar uma injeção sedativa no louco furioso, que a Junquilho anunciara pelo telefone. Encontram no fundo do sofá um homem calmo e desanuviado, que tem ainda traços de lágrimas no rosto sério. E ele então lhes conta lancinantemente, purgativamente, a sua história inteira.

Os médicos recusam-se a interná-lo como louco. A Junquilho, nos seus aposentos, acolitada de parentes e padres, tem sempre presente a cena culminante em que ele a insultara. 
Exige: - Ou os senhores levam Xavier para o Juqueri ou eu telefono para o secretário e mando prendê-lo outra vez!

Os médicos forçam o pobre-diabo a sair com eles. Ele agarra-se à casa, em cujo estribo rico sempre vivera. Quer falar com a cunhada. Suplica. Quer pedir perdão. Tudo é inútil. O carro fechado dos médicos, levando-o ao lado do chofer, faz a curva suave do jardim e o grande portão da vivenda se fecha para sempre sobre o pingente que caiu. Os médicos deixam-no numa esquina garoenta da cidade.

Xavier acorda na pensão que não poderá mais pagar. A Junquilho lhe negará agora a mesada miserável. Procura então um dos médicos que o haviam tratado tão humanamente na noite anterior: - Doutor, eu venho lhe pedir um favor... Que me interne como louco no hospital do Juqueri. Eu não tenho aptidões para viver aqui fora!

O médico arranja-lhe um bico de ajudante de farmácia, no Juqueri: E aí o seu drama se entrosa com o da sua verdadeira mãe, a Veva, que foi colhida das ruas do Triângulo, onde mendigava apupada, para um dos pavilhões do manicômio oficial.

A Veva é a matriarca que perdeu o seu reinado. Espécie de rei Lear feminino. Traída pelos seus entes mais caros, espoliada e expulsa, ela fora realizar pelas ruas centrais de São Paulo, no plano da esquizofrenia, as transações que teriam salvo sua fortuna, se a morte do filho legítimo não a tivesse entregue à voracidade conluiada de parentes e advogados. Arruinada, indo acoitar-se no quarto nauseabundo da negra velha que fora sua escrava, ela saía todas as manhãs para o coração "afarista" da cidade, onde se espedaçou o seu poder. Bancos, tabeliães, baiúcas de usurários, escritórios de advogados e corretores, pequenos botecos onde se almoça um sanduíche de lingüiça e um copo de água da torneira a conhecem. Ela hesita no Triângulo, às dez horas da manhã, um chapéu festivo na cabeça, uma pasta velha e cheia de papeluchos sob o braço. Mas os horários ativos começam, o rodar do lucro prossegue, o ritmo da cidade capitalista passa. A Veva, desde a sua ruína estabilizou-se na tragédia financeira, é o autômato na negociata, o boneco trágico do dinheiro em ação. Penetra nos tabeliães, manda em altas vozes lavrar escrituras imaginárias, paga hipotecas, emite cheques em papéis da rua e apresenta-os nos guichês atarantados dos bancos, exige pagamentos, execuções, penhoras, do homem da rua. Toda a sua desgraça se desenvolve no plano mágico da esquizofrenia. Dão-lhe níqueis para comer e as crianças da rua a atropelam. Conduziram-na uma tarde ao Juqueri, onde agora vem encontrá-la Xavier, seu filho natural. Culmina aí na Veva o poder de transferência com que se enriquece o seu isolamento da realidade.

"Meu filho!", exclama. "Você é meu filho!"

Xavier vai enfim ouvir a verdade, estribar o seu impulso definitivo na confissão máxima que sempre esperara. Deixará o Juqueri, interpelará a Junquilho, tomará advogados, reivindicará a imensa fortuna roubada de ambos. Mas a Veva o chama pelo nome do outro, o que morrera na posse exclusiva da legitimidade. A sua força autista evita que a realidade ponha entre ambos uma fonte segura de solidarização e de afeto. Ela restaura nele o filho morto.

Esvaziada de todo o lastro, a paranóia de Xavier se agarra à primeira excitação que encontra. Nas horas de folga, volta à vida e ao convívio turbulento dos bêbados do Beco do Escarro; seus amigos do xadrez. A vasa da revolução social atinge os botecos pitorescos do Triângulo. Novos complexos habitam a sua psique extenuada. E ele vai morrer na rua, num pseudo-assalto noturno, a um quartel que está de prontidão, numa vigília armada da cidade.

A Veva prossegue sozinha a sua ascensão demente. Ela realiza no Juqueri, que ela crê ser sua última fazenda, o que eu chamaria a curva das esquizofrenias de planalto. O planalto piratiningano não está longe dos planaltos esquizóides, que deram as civilizações individuais e marcadas da América - o planalto mexicano, o planalto incaico. Para ela "São Paulo venceu", e ela passeia, rasgada e suja, nas celas e nos pátios do manicômio, uma saia de 
uniforme das internadas, em que vê as cores brancas e pretas da bandeira paulista, símbolo da restauração dominadora de sua classe, afastada da realidade contemporânea.

São esses dois tipos, senhores congressistas, que trago em arcabouço à vossa presença. Os andaimes da construção psicológica não devem aparecer nas páginas do romance. Nelas, eles se dissimularão atrás da ação, sob os diálogos e as reações dos personagens. Mas, como vos disse no início, não aceito as improvisações da criação literária. Por isso ousei trazer-vos a análise desses dois personagens de Marco zero. 